\title{
ГАЛИТ И НАТРОАЛУНИТ КАК ЭОЛОВЫЕ МИНЕРАЛЫ В ЛАТЕРИТНЫХ БОКСИТАХ ПОЛУОСТРОВА КАЧ, ИНДИЯ
}

\author{
А. Д. Слукин ${ }^{1}$ Н. М. Боева ${ }^{1}$, Е. А. Жегалло ${ }^{2}$, Л. В. Зайцева ${ }^{2}$, Е. С. Шипилова ${ }^{1}$ \\ ${ }^{1}$ Институт геологии рудных месторождений, \\ петрографии, минералогии и геохимии РАН, г. Москва \\ ${ }^{2}$ Палеонтологический институт им. Борисяка РАН, г. Москва
}

Поступила в редакцию 19 ноября 2019 г.

\begin{abstract}
Аннотация: процессы латеритизации и бокситизациии на территории Индостана начались в палеоцене и продолжаются по сей день. Но на западе и северо-западе Индии в результате колебательных тектонических движений прибрежные участки дважды затоплялись морем и вновь осушались. При этом бокситы полуострова Кач были перекрыты квасцовыми глинами, черными сланцами, лигнитами, мергелями и известняками. После плейстоцена происходило медленное поднятие, и бокситы были обнажены в условиях климата тропических пустынь. Залив Большой Качский Ранн в сухой сезон превращался в соляную пустыню. Процессы минералообразования выразились в широком развитии карбонатов, гипса, натроалунита, квасияов и галита. Источниками $\mathrm{Na}$ и Cl были аэрозоли солей Качского Ранна, а источниками $\mathrm{Al}$, SO, $\mathrm{K}$ - бокситы и продукты выветривания квасиовых глин. Установлено, что засоление бокситов происходило при участии микроорганизмов.
\end{abstract}

Ключевые слова: боксит, гиббсит, гематит, галит, натроалунит, квасцыь, биоминеральные пленки, микроорганизмы, полуостров Кач, Индия.

\section{HALITE AND NATROALUNITE AS AEOLIAN MINERALS IN THE LATERITE BAUXITES OF KUTCH, INDIA}

\author{
A. D. Slukin ${ }^{1}$, N. M. Boeva ${ }^{1}$, E. A. Zhegallo ${ }^{2}$, L. V. Zaytseva ${ }^{2}$, E. S. Shipilova ${ }^{1}$ \\ ${ }^{1}$ Institute of Geology of Ore Deposits, Petrography, \\ Mineralogy and Geochemistry, Russian Academy of Sciences, Moscow \\ ${ }^{2}$ Borisyak Paleontological Institute, Russian Academy of Sciences, Moscow
}

Received 19 November 2019

\begin{abstract}
Hindustan started in the Paleocene and continue up to now. But in the West and North-West of India, as a result of oscillatory tectonic movements, coastal areas were twice flooded by the sea and again drained. The bauxites of the Kutch Peninsula were overlain by alum clays, black shales, lignites, marls and limestones. After the Pleistocene, there was a slow uplift, and bauxites were exposed in the climate of tropical deserts. The Gulf of Great Kutch Rann in the dry season turned into a salt desert. The processes of mineral formation were expressed in the wide development of carbonates, gypsum, natroalunite, alum and halite. The sources of $\mathrm{Na}$ and $\mathrm{Cl}$ were aerosols of Kutch Rann salts, and the sources of $\mathrm{Al}, \mathrm{SO}_{4}, \mathrm{~K}$ were bauxites and weathering products of alum clays. It is established that salinization of bauxite occurred with the participation of microorganisms.
\end{abstract}

Key words: bauxite, gibbsite, hematite, halite, natroalunite, alum, biomineral films, microorganisms, Kutch Peninsula, India. 


\section{Введение}

Индия - одна из стран, обладающих крупнейшими запасами бокситов. Большая часть этих запасов сосредоточена в месторождениях латеритного генезиса [1]. Они являются конечными продуктами выветривания алюмосиликатных пород в условиях тропического переменно-влажного климата в благоприятных тектонических и геоморфологических обстановках. Тектоническая обстановка должна быть стабильной или сопровождаться слабыми колебательными движениями земной коры в течение достаточно длительного периода времени (тысячи и миллионы лет), необходимого для формирования латеритного профиля. Геоморфологическая обстановка характеризуется спокойным сглаженным рельефом, в котором пологие горизонтальные, выпуклые и вогнутые вершины гор или холмов способны принимать на свою поверхность максимально возможное количество дождевых осадков и фильтровать их через себя.

Наглядным примером латеритного профиля может служить миниатюрный, по геологическим меркам, останец, вычлененный эрозионными процессами из цепи столовых холмов (рис. 1). Его скальная вершина с отвесными стенами сложена кавернозным латеритом, состоящим из тесной смеси гематита, гетита, гиббсита и каолинита. Нижняя часть скалы сложена каменистыми гиббситовыми бокситами. На пологих склонах холма обнажены зоны каолинита и монтмориллонита, а в его основании - дезинтегрированные базальты.

Геохимия процессов выветривания и бокситизации алюмосиликатных пород заключается в посте- пенном растворении и выносе щелочных и щелочноземельных элементов и кремния, относительном и абсолютном накоплении элементов-гидролизатов: алюминия, железа, титана, местами, марганца и некоторых других [2]. Этот геохимический процесс выражается в полном изменении состава материнского субстрата и образовании ряда совершенно новых гипергенных минералов, формирующих латеритный профиль [3]. Состав материнских пород оказывает существенное влияние на динамику процесса и на продукты выветривания. Кварцсодержащие породы, благодаря прогрессирующему растворению зерен кварца и возникновению на их месте пор, отличаются интенсивной фильтрацией дождевых вод, глубоким проникновением кислорода, длительным существованием окислительной обстановки. На них развиваются зоны каолинов, сложенные каолинитом, гетитом и гематитом, и бокситов, сложенные гиббситом, гематитом и гетитом с реликтами кварца [4]. На базальтах, долеритах и других основных породах ниже каолина образуется мощный горизонт монтмориллонита. Во время муссонных дождей монтмориллонит разбухает, тампонирует все пути фильтрации и способствует возникновению сезонной застойной восстановительной обстановки. При этом $\mathrm{Fe}^{3+}$ переходит в $\mathrm{Fe}^{2+}$, растворяется и постепенно выносится из каолинов и бокситов. Вынос растворов осуществляется путем бокового высачивания, капиллярного подъема и эвапотранспирации. При встрече с кислородом $\mathrm{Fe}^{2+}$ окисляется, переходит в $\mathrm{Fe}^{3+}$ в виде гетита и гематита, формируя собственно латериты [5].

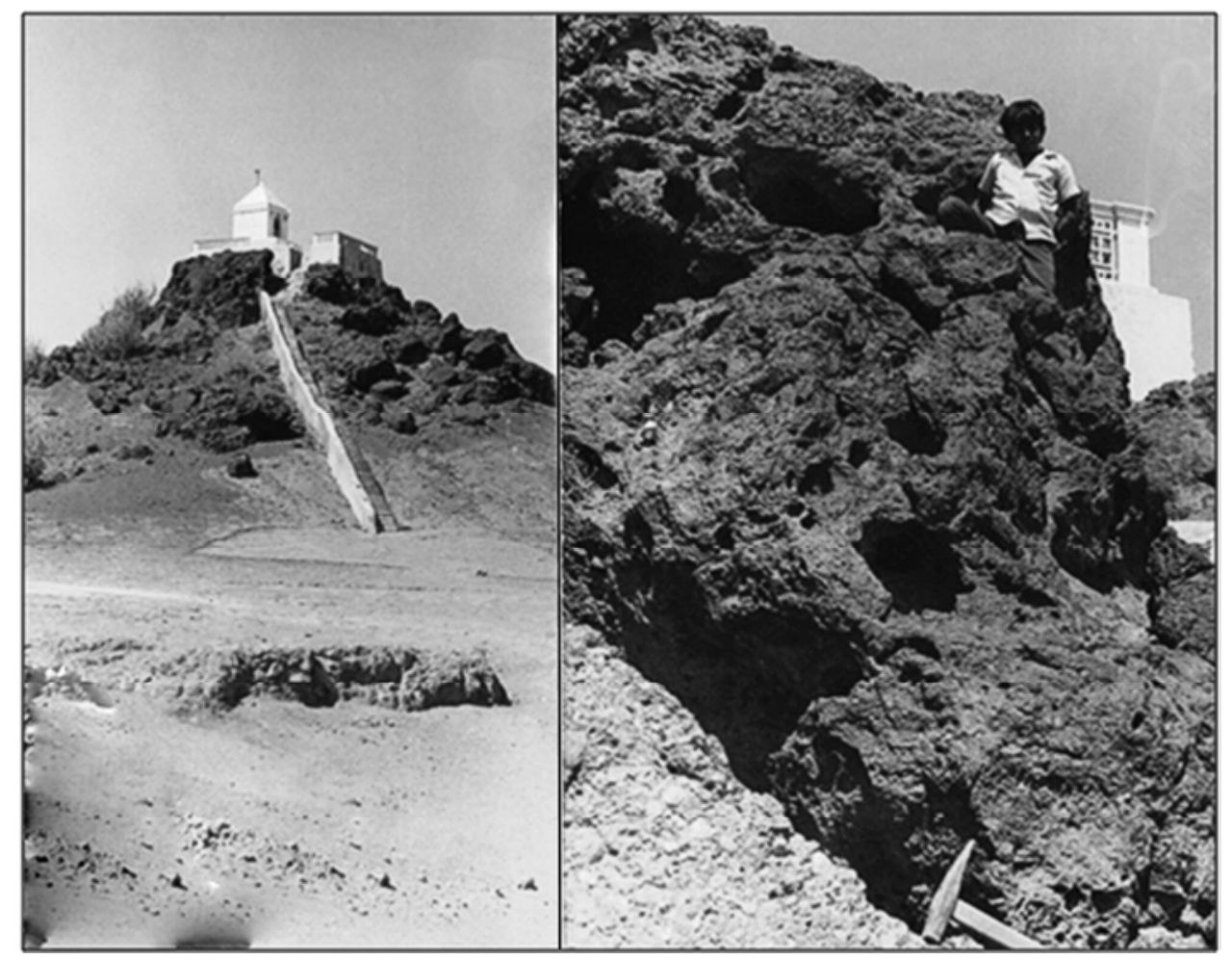

Puc. 1. Столовый холм, как «миниатюрный» останец латеритного профиля на базальтах. Окрестности деревни Шерди. 
Однако сравнительно простые минеральные ассоциации продуктов латеритизации существенно усложняются при изменении тектонических, геоморфологических и климатических условий. Прибрежные низменности западного побережья Индии представляют собой поднятое дно моря, ранее непосредственно примыкавшее к суше [6]. Слагающие их породы неоднократно поднимались над уровнем моря, расчленялись реками, выветривались, погружались в море, покрывались новыми порциями осадков, вновь поднимались и выветривались. Таким образом, в разрезе прибрежно-морских отложений на каолинитовых глинах сформировались, по крайней мере, два бокситоносных латеритных профиля [7]. Эти события особенно отчетливо проявились в южной части Индостана на Малабарском побережье в условиях переменновлажного тропического климата, существующего с позднего мела до наших дней. Такие условия оказались благоприятными для образования и сохранности бокситов, сложенных гиббсит-гематитовой ассоциацией (месторождение Палайангади, штат Керала).

Северная часть западного побережья, замыкается полуостровами Катхиявар и Кач; на последнем сосредоточены главные месторождения бокситов штата Гуджарат (рис. 2). Здесь латеритизации подверглись не только прибрежно-морские и аллювиальные отложения, но и низкие холмы-останцы расчлененного траппового плато. Траппы сложены мел-палеоценовыми базальтами. В палеоцене в условиях переменновлажного тропического климата здесь также сформировались бокситоносные латеритные коры выветривания. В раннем и среднем эоцене они были затопле- ны морем и перекрыты глинистыми сланцами со слоями лигнитов и песчаниками. В позднем эоцене эта территория была поднята и подвержена повторной латеритизации. С миоцена до плейстоцена включительно она была вновь затоплена морем, и латериты были перекрыты песчаниками, глинистыми сланцами, мергелями и известняками. После плейстоцена происходило медленное поднятие, но еще в 19 веке Кач на географических картах изображался островом. В настоящее время Кач представляет собой полуостров, занятый скалистыми столовыми холмами высотой до 300 м и окаймленный широкой песчаной полосой прибрежной низменности. К северу от него простирается Большой Качский Ранн. Около 2500 лет назад в него впадала река Инд, но постепенно она на 150 км сместилась на запад, климат стал аридным, и началось наступление пустыни Тар. В зимний сухой сезон Ранн предстает как огромная белая равнина, на которой местное население добывает поваренную соль (рис. 3). В период летних муссонов Ранн затопляется. Самым жарким месяцем является май: его среднемесячная температура колеблется около $35,5^{\circ} \mathrm{C}$, а максимальная поднимается выше $49^{\circ} \mathrm{C}$. В силу избыточного перегрева возникают сильные пыльные бури. В отличие от Малабарского побережья, где выпадает 15002500 мм осадков в год, на Каче их количество составляет 350-370 мм [6]. Во время нашего посещения Кача аборигены сообщили, что там не было дождей 4 года. Небольшой город на плоской вершине останца траппового плато был покинут жителями, а его четыре глубоких бассейна для сбора дождевых вод оказались совершенно высохшими.

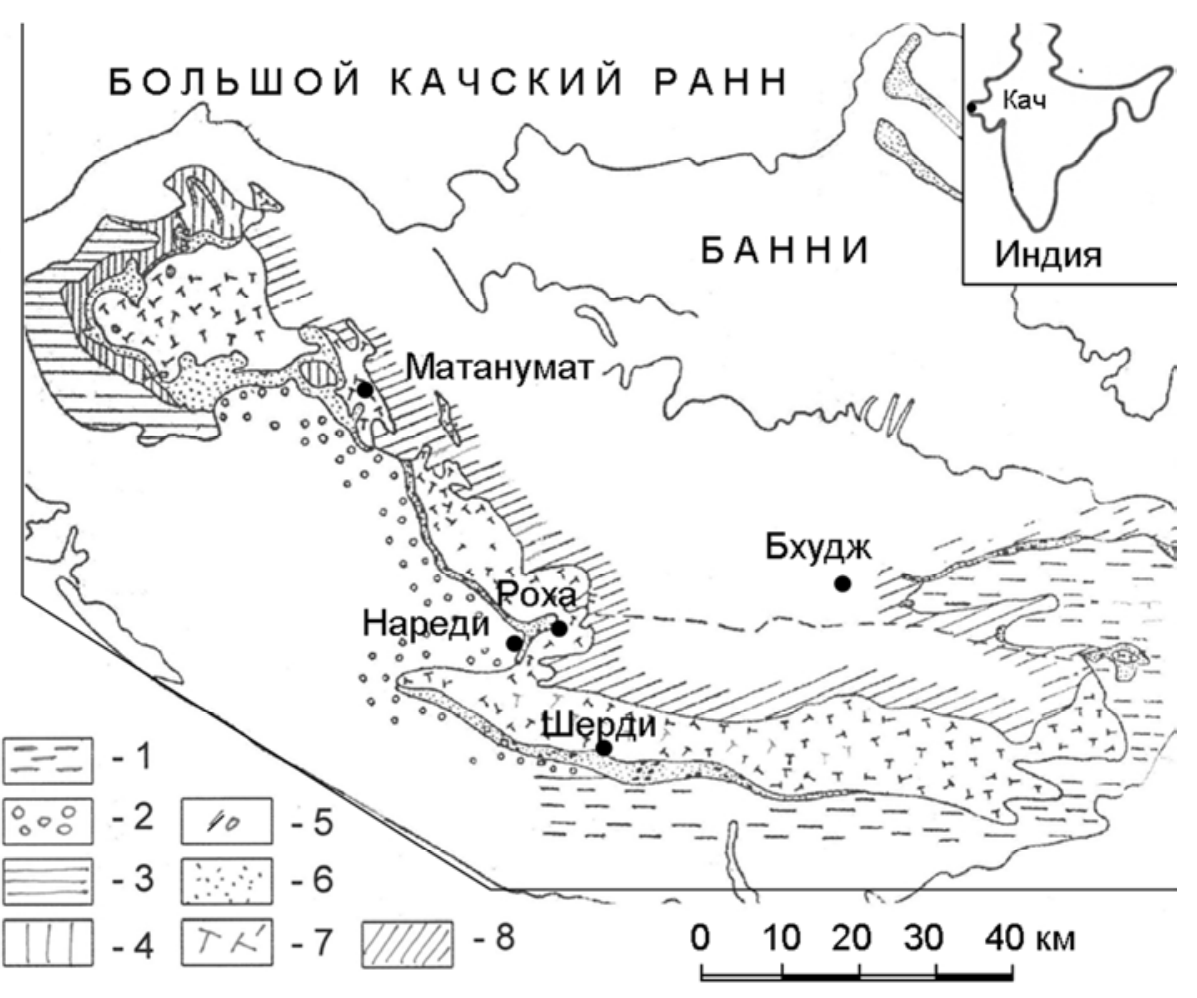

Puc. 2. Схематическая геологическая карта западной части полуострова Кач и ее положение на территории Индии (врезка) (по материалам Sahasrabudhe, 1978; Слукин, 1991): 1 - Мангхар серия: четвртичные отложения: пески, глины, аллювий; 2 - Слои Гадж: останцы тектонического покрова: конгломераты, известняки; 3 - нуммулитовые известняки; 4 - гипсоносные сланцы; 5 - бокситы; 6 - субнуммулитовая группа: квасцовые глины, глины латеритизированных пирокластов и вулканические осадки деканских траппов, битумизированные и пиритоносные сланцы; 7 - деканские траппы; 8 - юрские отложения. 


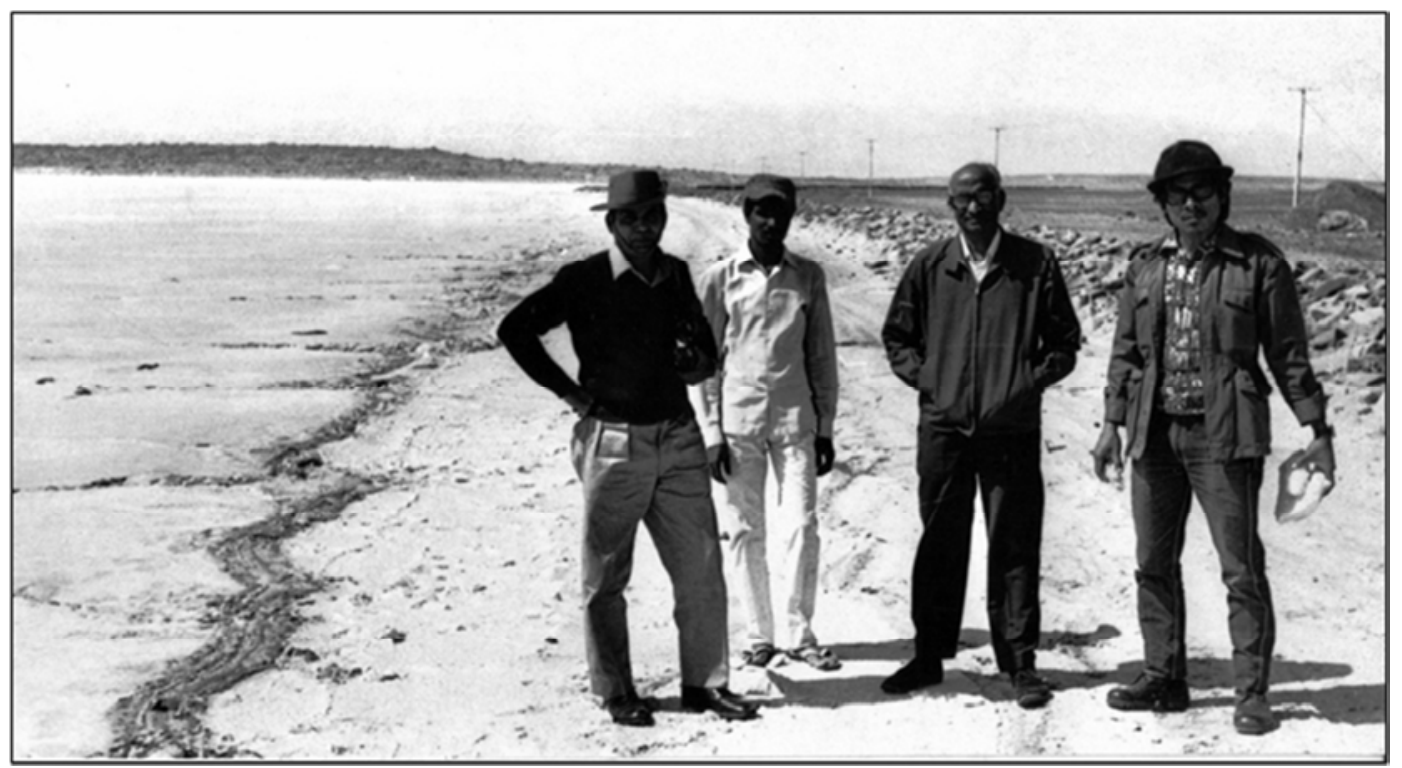

Puc. 3. Большой Качский Ранн, как соляная пустыня во время сухого зимнего сезона.

Объекты, материалы и методы исследования

В результате обзора опубликованных данных по бокситам Индии и личных исследований геологии, минералогии и геохимии основных типов их месторождений [8], мы обратили особое внимание на п-ов Кач, как объект с очень сложной историей. Он отличается от большинства классических латеритов, а Индия - родина самого термина «латерит» и место нахождения памятного знака этого литотипа. Большинство латеритов Индостана формировалось и существует в относительно стабильных тектонических, геоморфологических и климатических условиях. На п-ове Кач, как показано выше, они менялись радикально. В частности, тропический влажный и сухой климат, или климат муссонных саванн, сменился на климат тропических и субтропических пустынь. В этих условиях процессы минералообразования не прекратились, но они пошли в ином направлении и выразились в широком развитии антагонистических латеритам ассоциаций: карбонатов (кальцита, сидерита), сульфатов (гипса), двойных сульфатов (алунита, ярозита, квасцов, галотрихита) и хлоридов (галита). Кроме того, бокситы в эоцене погружались в море и вновь осушались. При этом они оказывались в восстановительных условиях мелководной морской среды, в которой образовался шамозит $2\left[\left(\mathrm{Fe}^{2+}, \mathrm{Mg}\right.\right.$, $\left.\left.\mathrm{Fe}^{3+}\right)_{5} \mathrm{Al}\left(\mathrm{Si}_{3} \mathrm{Al}\right) \mathrm{O}_{10}(\mathrm{OH}, \mathrm{O})_{8}\right]$. Все пострудные минералы распространены спорадически, а их общее количество достигает $15 \%$. Показательно, что современные отвалы разрабатываемых карьеров быстро минерализуются, и куски монтмориллонитизированных, каолинитизированных и гиббситизированных базальтов покрываются обильными корочками кальцита, сидерита, арагонита, гипса и галита.

Нами предполагалось, что генезис вторичных минералов различен и в их образовании участвуют процессы восстановления и окисления, эвапотранспирации, биогеохимического взаимодействия и эоловые.
Влияние последних подтверждалось опытом наблюдений и результатами изучения продуктов эолового переноса в центральных частях Индостана, в пустынях Гоби в Монголии, в латеритах островов Лос (Гвинея), на Сицилии и в «море мрака» в Атлантике [9].

Присутствие вторичных минералов в бокситах пова Кач отмечалось и ранее, но их морфология была изучена слабо [10-12]. Наиболее основательно был изучен натроалунит, облик кристаллов которого был продемонстрирован на ряде электронно-микроскопических снимков [13]. В дополнение к предыдущим исследованиям, нами была предпринята попытка выявить, по возможности, все формы нахождения галита и сопровождающих его минералов с помощью электронномикроскопического анализа и оценить его влияние на судьбу главных минералов бокситов: гиббсита и гематита.

Исследования проводились с помощью сканирующих электронных микроскопов CamScan-4 (Cambridge) и TESCAN VEGA IIXMU (Tescan).

\section{Вторичные минералы}

Галит находится на поверхности обнаженных пород латеритного профиля и глубоко проникает в их поры и каверны. Он с трудом различается невооруженным глазом, а в данных химического анализа бокситов, латеритов и каолинов обнаруживается по неожиданным парадоксально высоким содержаниям $\mathrm{Na}$ и $\mathrm{Cl}$. Присутствие галита в количестве 8,2 \% зафиксировано в светло-серых бокситах, содержащих $80 \%$ гиббсита с примесью 3,4 \% титаномагнетита, 6,4 $\%$ гематита и $2 \%$ каолинита, а также в биминеральных бокситах с переменными соотношениями гиббсита и бемита, достигающими величин 50:50. Красноцветные бокситы и латериты сложены гиббситом (30$60 \%$ ), гематитом (20-60\%), каолинитом (3-20\%), титаномагнетитом (2-4\%) и включают 1-9 \% галита и, местами, до $10 \%$ натроалунита. Первые попытки 
определить форму нахождения хлорида натрия позволили обнаружить под сканирующим электронным микроскопом аморфное вещество в виде сплошных пленок и изолированных пятен, подобных растекшемуся клею (рис. 4 а). Дальнейшие наблюдения позволили установить, что некоторые из этих пленок частично или полностью раскристаллизованы, и в них выделились отдельные кубические кристаллы, местами образовавшие сплошные корки (рис. 4 б, в). На поверхности пленок и в близповерхностных частях латеритов и бокситов широко распространены обильные биоморфозы: кольцеобразные (по Romeria), дискообразные (по Synechococcus) и чашеобразные (по Planctomicca), овоидные и другие. Многие кристаллические корки псевдоморфно замещены гематитом. Химический состав, как пленок, так и кристаллов довольно разнообразен и охватывает элементы: С, О, $\mathrm{Na}, \mathrm{Al}, \mathrm{Cl}, \mathrm{S}, \mathrm{Fe}$ и примеси $\mathrm{Si}, \mathrm{K}$ и Ti. Одни пленки включают все эти элементы, другие проявляют четкую специализацию, и в них доминируют $\mathrm{Na}, \mathrm{Cl}$ или $\mathrm{Al}, \mathrm{S}, \mathrm{Na}, \mathrm{O}, \mathrm{K}, \mathrm{Si}$ или $\mathrm{Fe}, \mathrm{O}$.

Несмотря на внешнее сходство всех кубических кристаллов, в них проявлены слабые или заметные различия. Одни из них обладают равными квадрат-
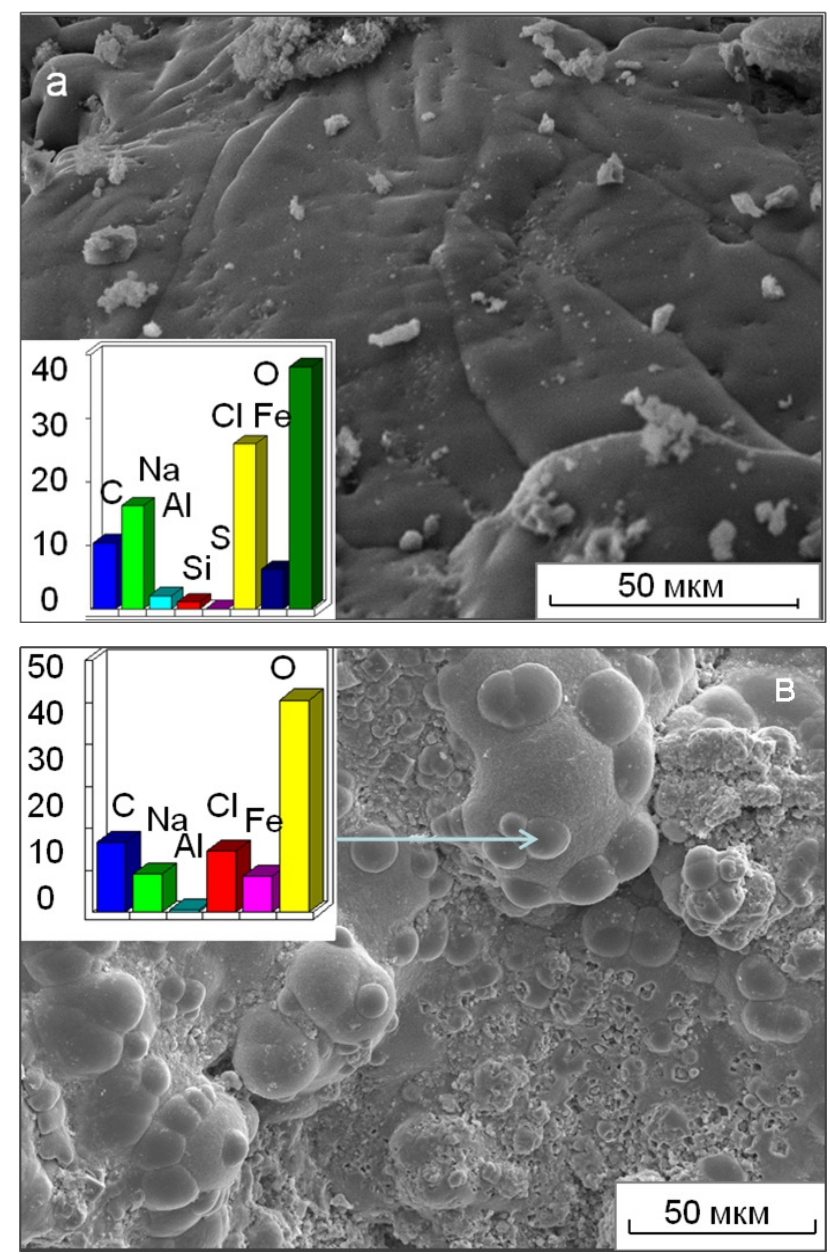

ными гранями и полностью отвечают кубу с размерами ребер до 10 мкм. Их химический состав отвечает галиту - $\mathrm{NaCl}$. Другие кристаллы несколько вытянуты, и их облик соответствует параллелепипеду. Средний размер его граней 7x4 мкм. Самый крупный кристалл имеет грани размером $65 \times 40$ мкм. Такими формами обладает натроалунит - $(\mathrm{Na}, \mathrm{K})(\mathrm{Al}, \mathrm{Fe})_{3}\left(\mathrm{SO}_{4}\right)_{2}$ $(\mathrm{OH})_{6}$. Его химический состав включает все вышеперечисленные элементы.

Галит и натроалунит по трещинам проникли вглубь бокситовых тел и отложились в них в виде плотных натеков или параллельно-волокнистых масс. Толстые (10-15 мкм) биоминеральные пленки образуют сферические и полусферические тела, имеющие радиально-лучистое строение. Все вторичные минералы находятся в состоянии разной степени сохранности. Одни кристаллы имеют первозданный вид, без следов коррозии, растворения и псевдоморфоз. Другие кристаллы полностью растворились и исчезли, оставив после себя псевдоморфозы в виде пленок гематита. Между первыми и вторыми имеется множество переходных состояний, обусловленных растворением и выносом щелочных и щелочноземельных элементов, окислением железа и образованием гематита.
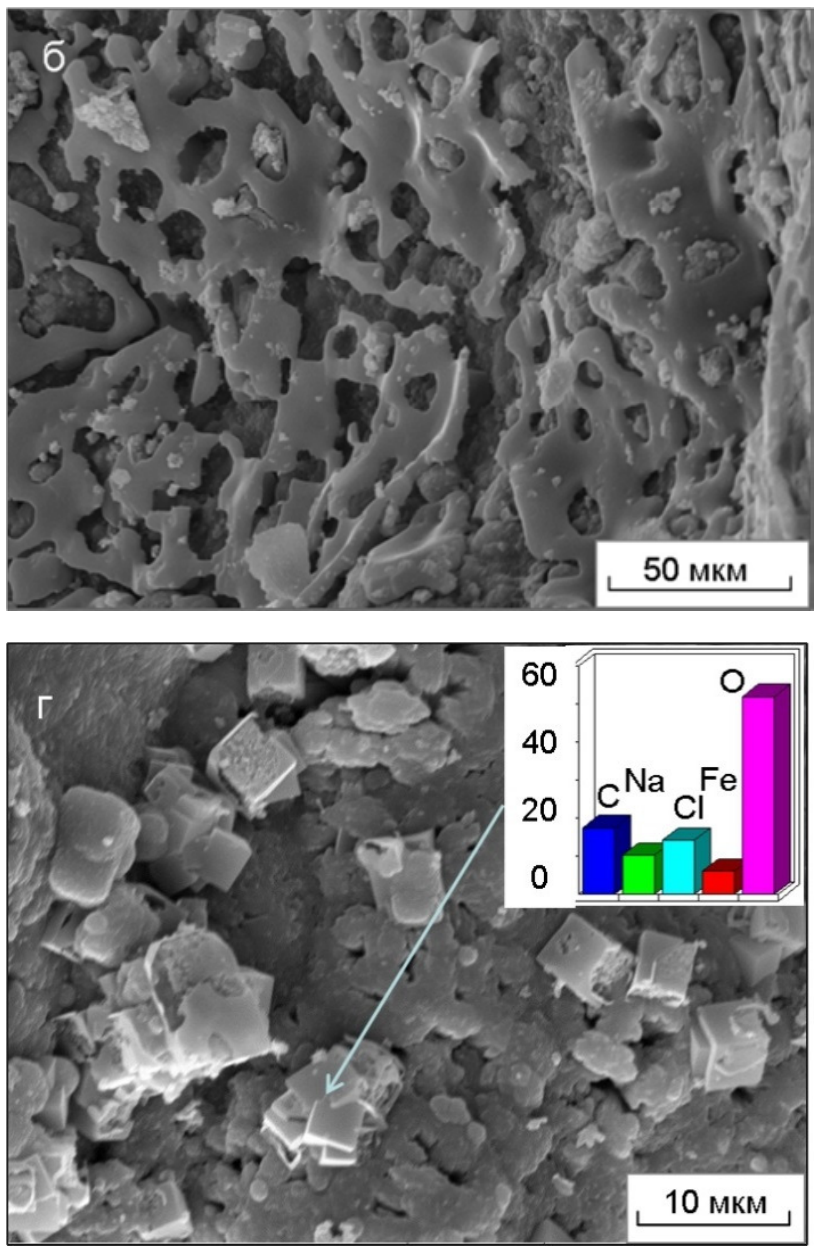

Puc. 4. Формы нахождения $\mathrm{NaCl}$ в бокситах полуострова Кач: $a$ - биоминеральная пленка и ее состав; $\sigma$ и $b$ - формы усыхания рассолов; 2 - кристаллы галита и их состав. 
Генезис галита, натроалунита

и гематита в бокситах полуострова Кач

Галит, натроалунит, гиббсит и гематит в породах латеритного профиля представляют собой запрещенную для латеритизации парагенетическую ассоциацию. Их совместное нахождение обусловлено геологической историей региона и изменяющимися тектоническими, геологическими и геоморфологическими условиями.

Изученные бокситы являются продуктом латеритизации пирокластических фаций деканских лавовых потоков, датируемых ранним эоценом-поздним мелом [12]. Так как в перекрывающих эоценовых и третичных отложениях отсутствуют следы латеритизации, возраст латеритов относится к раннему эоцену. В среднем эоцене произошло опускание территории Кача, и образовались известняки, лигниты, квасцовые глины и черные сланцы с большим содержанием пирита. Во время постплиоценового поднятия эти перекрывающие отложения были эродированы, и латеритные покровы были вновь обнажены. Однако за это время на Каче установился климат тропических пустынь, и процессы латеритизации были максимально заторможены.

Несомненно, натроалунитизация латеритов началась после отложения пиритоносных сланцев и лигнитов. Считается, что окисление пирита привело к появлению сульфатных растворов, которые могли выщелачивать натрий из этих покровных отложений. Реакция сульфатных и натрийсодержащих растворов с каолинитом в сапролитах ниже бокситов могла стать ведущим процессом натроалунитизации [13].

Такие выводы о генезисе натроалунита были сделаны по результатам изучения латеритного профиля на базальтах в средней части цепи холмов в 110 км к C3 от Бхуджа. Изученные нами латеритные профили на базальтах и элювиальных образованиях находятся вблизи населенных пунктов Шерди, Нареди и Роха Хилл к западу и юго-западу от Бхуджа в южной части цепи холмов. Геологическая обстановка у них сходна: латеритизированные базальты соседствуют с лигнитами, черными сланцами и квасцовыми глинами, которые наблюдаются в естественных обнажениях и карьерах. В последних хорошо видны следы растворения и высыхания квасцов и многочисленные потеки на вертикальных стенах, вызванные ежесуточными колебаниями температуры и влажности.

Особенности современного климата полуострова Кач должны были привлечь внимание исследователей латеритов. Кач является частью области с сухим и жарким климатом (северная аридная зона). В нее входит и большая часть Западного Пакистана - непосредственного соседа Кача. Они разделены огромным Качским Ранном, который в сухой сезон представляет собой соляную равнину (рис. 3). В аридных зонах главным источником осадочного материала является эоловая пыль [14; 15]. Каждая пустыня - это центр бурь, выносящих огромное количество аэрозольного материала. Попадая в тропосферу, этот материал пе- реносится на многие тысячи километров. В частности, доказано решающее значение эоловой седиментации для всей северной и экваториальной части Индийского океана [16]. Большая часть минерального состава осадков Аравийского моря, омывающего Кач, принесена ветром из пустынных областей Северной Индии и Западного Пакистана. Несомненно, эти ветры развеивали соль Качского Ранна и рассеивали ее по всей поверхности полуострова. Соль покрывала поверхность всех обнаженных пород. В особенно высокопористых и кавернозных латеритах и бокситах, она заполняла поры, каверны и трещины. В условиях ежесуточно меняющихся температуры и влажности, она растворялась, образуя рассолы и биопленки, которые быстро высыхая, создавали причудливые по форме выделения аморфного вещества с химическим составом $\mathrm{NaCl}$. При более длительном высыхании растворов и биопленок, в них происходила кристаллизация хлорида натрия и образование кубических кристаллов галита (рис. 4 г, 5 а). Ветры с юга и запада приносили аэрозольный материал из квасцов и алунитов, а главным поставщиком алюминия являлись бокситы, где зафиксированы следы растворения и коррозии боксита. Основным источником натрия была эоловая соль Качского Ранна. Это подтверждается присутствием многочисленных соленых биопленок, кристаллов галита и продуктов его растворения. Перманентное длительное участие эолового галита в процессах минералообразования в условиях пустынного климата подтверждается повсеместным присутствием гематитовых псевдоморфоз по галиту и алуниту (рис. 5 б, в, г). Несомненно, источником натрия, калия, алюминия и сульфатов, были аэрозоли квасцов, принесенные южными и юго-западными ветрами. Существование галита, алунита и квасцов в бокситах довольно эфемерно, но оно не проходит бесследно. Как правило, они растворяются и от них остаются ажурные псевдоморфозы гематита, которые в массе создают в бокситах участки ящичных текстур. Соль воздействовала на кристаллы гиббсита, создавая специфические фигуры растворении (рис. 6 а-г).

В нескольких последних работах нами показано огромная роль биоты, в том числе микроорганизмов, в образовании пород и минералов латеритного профиля [17-22]. Нам было интересно узнать о присутствии биоты в соленых бокситах. В результате наших наблюдений под электронными микроскопами было установлено широкое развитие в бокситах гифов грибов, корней трав и кустарников, биоминеральных пленок и микроорганизмов (Romeria, Synechococcus, Planctomicca и др.). Почти все они превратились в гематитовые фито- и биоморфозы (рис. 7 а-г).

Процессы латеритизации и бокситизации на территории Индостана начались в палеоцене и продолжаются по сей день. Но на западе и северо-западе Индии в результате колебательных тектонических движений прибрежные участки дважды затоплялись морем и вновь осушались. При этом бокситы полуострова Кач были перекрыты квасцовыми глинами, черными 

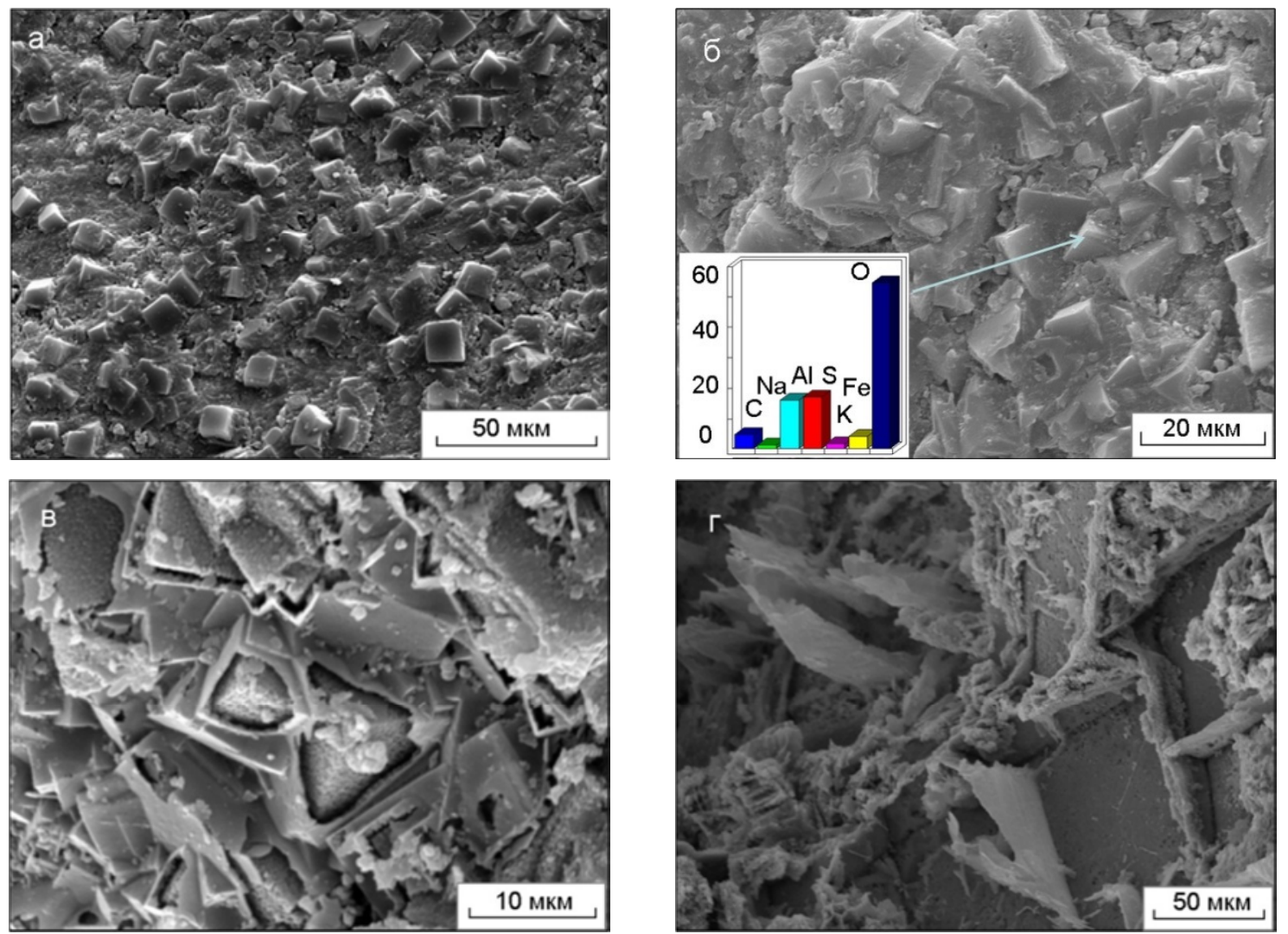

Puc. 5. Галит, натроалунит и гематит в бокситах: $a$ - кристаллы галита, $\sigma$ - кристаллы натроалунита, 8 - промежуточные формы растворения галита и образование псевдоморфоз гематита; г-псевдоморфоза гематита по натроалуниту.
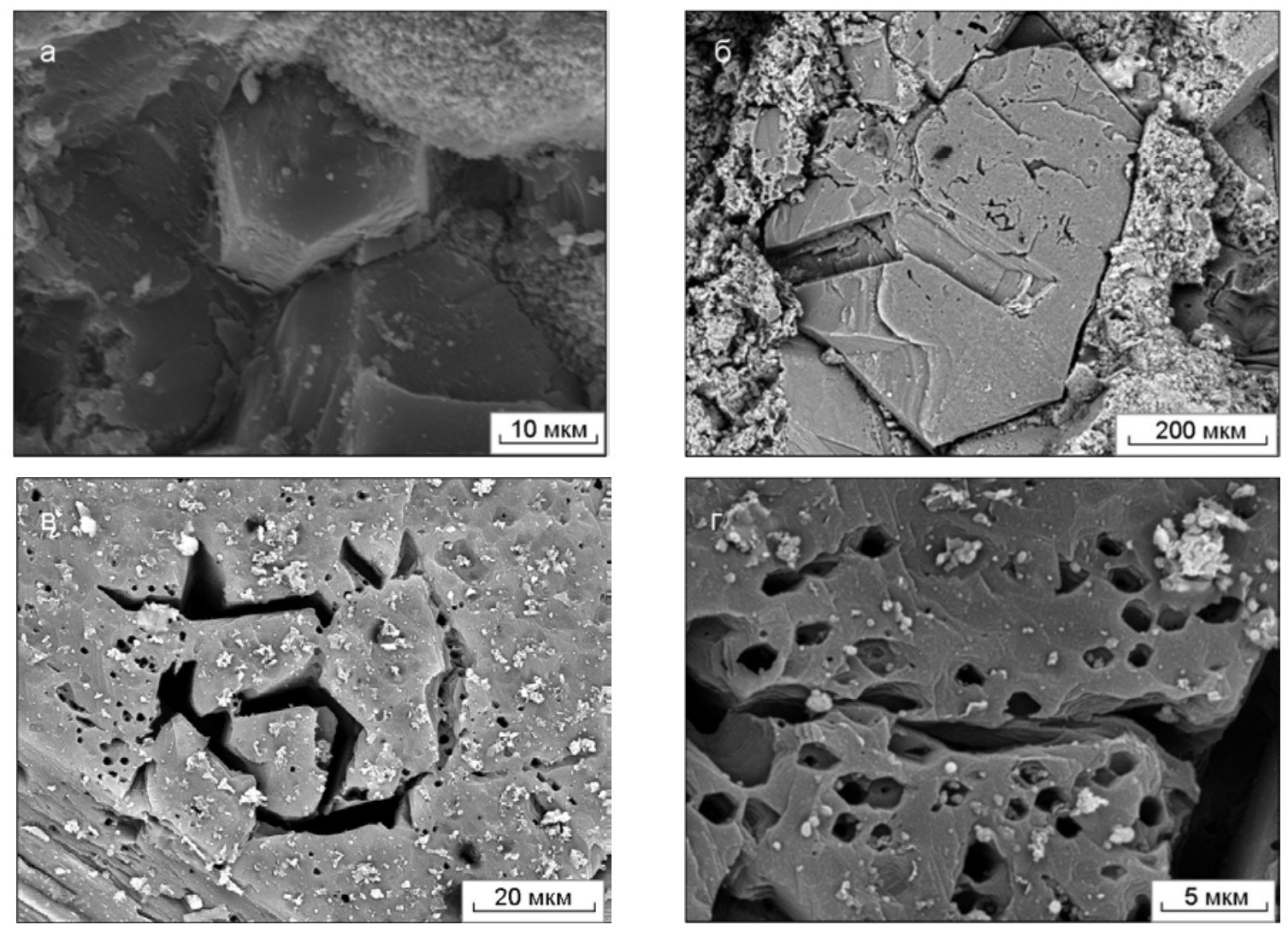

Puc. 6. Форма нахождения гиббсита в соленых бокситах: $a$ - свежий кристалл гиббсита под покровом соли: 6 и 8 - гиббсит со следами коррозии и растворения (в- деталь); 2 - гексагональные каналы растворения гиббсита. 

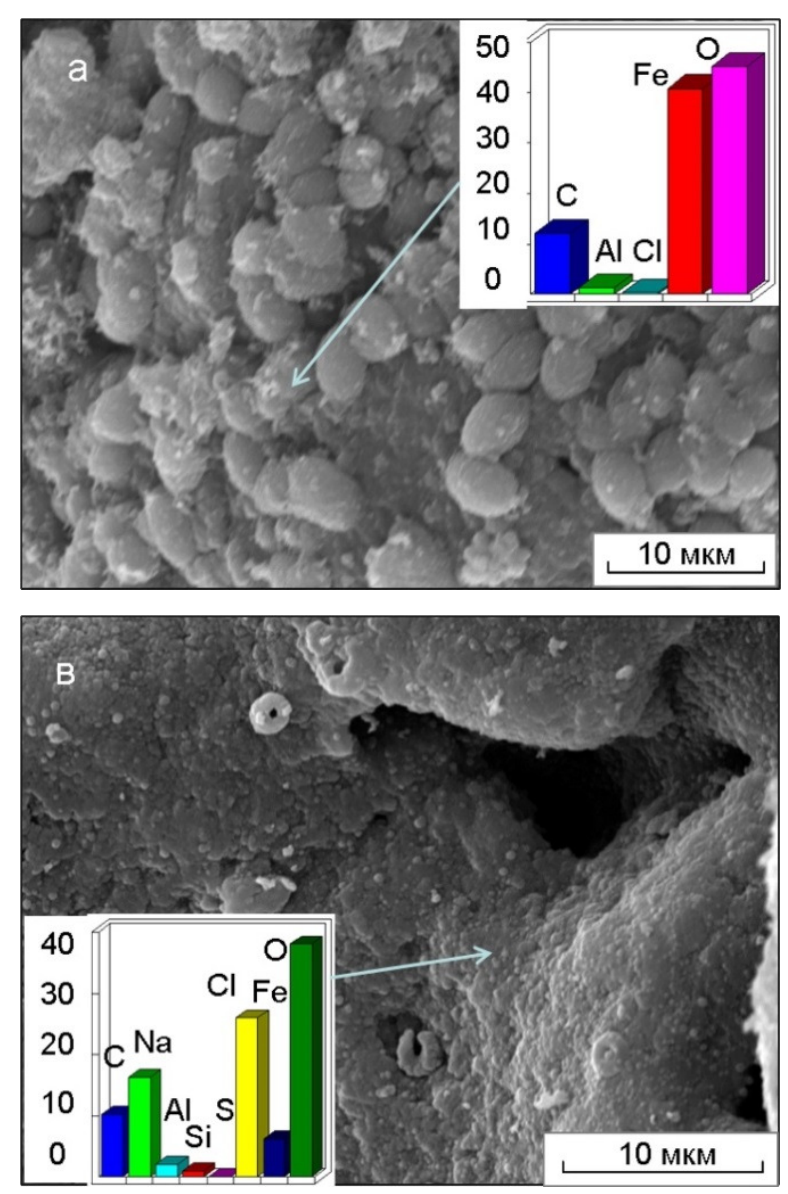
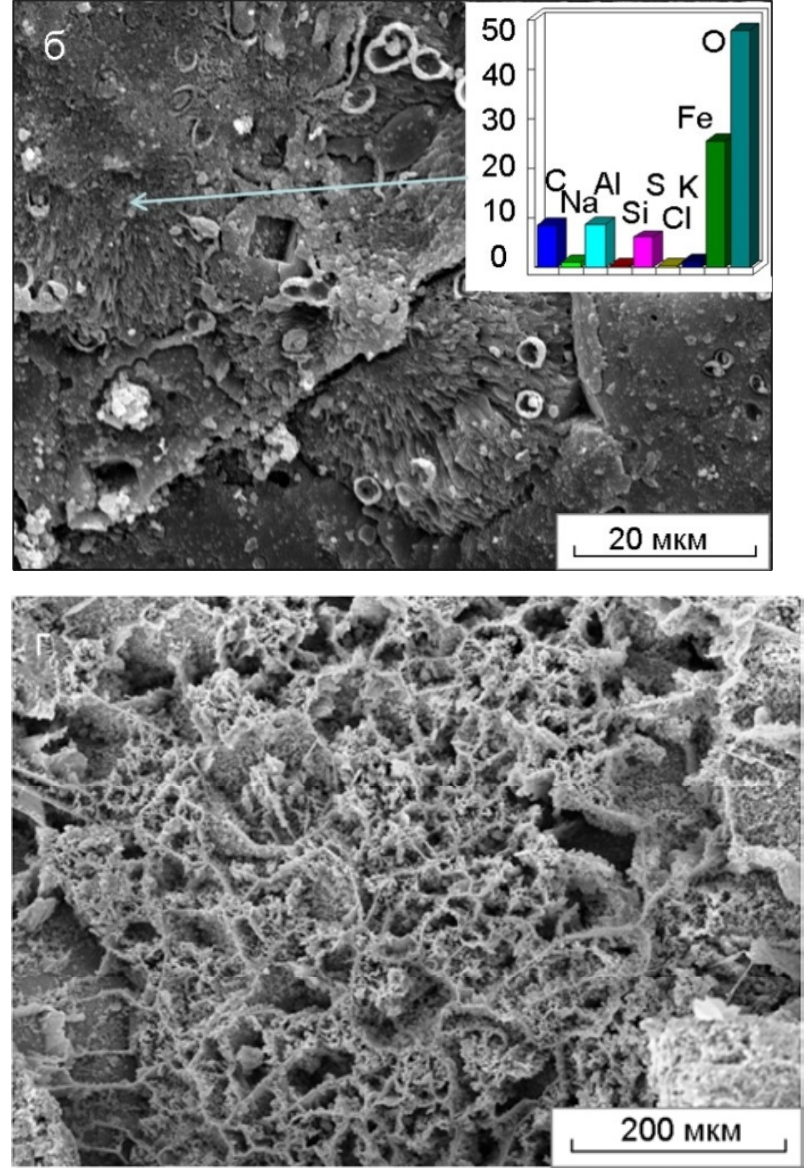

Puc. 7. Биоморфозы в соленых бокситах: $a$ - биоморфозы гематита по Synechcoccus; $\sigma$ - биоморфоза гематита по Planctomicса и реликтам натроалунита; 8 - биоморфозы по микрофауне; 2 - гематитовая фитоморфоза, покрытая солью.

сланцами, лигнитами, мергелями и известняками. После плейстоцена происходило медленное поднятие, и бокситы были обнажены в условиях климата тропических пустынь. Залив Большой Качский Ранн в сухой сезон превращался в соляную пустыню. Процессы минералообразования выразились в широком развитии карбонатов, гипса, натроалунита, квасцов и галита. Источниками $\mathrm{Na}$ и $\mathrm{Cl}$ были аэрозоли солей Качского Ранна, а источниками $\mathrm{Al}, \mathrm{SO}_{4}, \mathrm{~K}$ - бокситы и продукты выветривания квасцовых глин. Установлено, что засоление бокситов происходило при участии микроорганизмов.

Работа выполнена при поддержке госзадания ИГЕМ РАН № 0136-2014-0004, программы Президиума РАН № 17, гранта РФФИ № 17-04-00324.

\section{ЛИТЕРАТУРА}

1. Bardossy, G. Lateritic bauxites / G. Bardossy, G. J. J. Aleva. - Akademiai Kiado: Budapest, 1990. - 624 p.

2. Микроморфология и генетические взаимоотношения главных гипергенных минералов бокситоносных латеритных профилей (по результатам электронно-микроскопического изучения) / А.Д. Слукин [и др.] // Новые данные о минералах. - 2015. - В.50. - С. 50-61.

3. Коры выветривания и связанные с ними полезные ископаемые / А. Д. Савко [и др.]. - Воронеж : Истоки, 2007. $355 \mathrm{c}$.
4. Nandi, A. K. Essential differences in mineralogy and geochemistry of Indian lateritic bauxites formed on acid and basic rocks / A. K. Nandi, A. D. Slukin // Travaux ICSOBA, Zagreb. - 1983. - V. 13. - P. 145-155.

5. Слукин, А.Д. Белые латеритные бокситы как продукт сезонных изменений окислительных и восстановительных условий в процессе выветривания / А. Д. Слукин // Докл. АН СССР. - 1983. - Т. 272. - № 1. - С. 166-170.

6. Сингх, Г. География Индии / Г. Сингх. - М.: Мир, 1980. $-538 \mathrm{c}$.

7. Soman, K. Lateritization cycles and their relation to the formation and quality of kaolin deposits in south Kerala, India / K. Soman, A.D. Slukin // Proceedings of an International Seminar on Laterite, Oct. 14-17. - 1985. - Tokyo, Japan. Chemical Geology, 1987. - V. 60. - № 1/4. - P. 273-280.

8. Бемит-диаспоровые бокситы провинции Джамму, Индия, как продукты переотложения латеритных кор выветривания различных горных пород / Н.С. Бортников [и др.] // Вестн. Воронеж. гос. ун-та. Сер.: Геология. - 2014. - № 2. C. 23-31.

9. Ранние стадии преобразования современных осадков северной аридной зоны Восточной Атлантики / Ж. В. Домбровская [и др.] // ДАН. - Т. 362. - № 6. - С. 798-802.

10. Слукин, А. Д. Вторичные изменения бокситов Индии / А. Д. Слукин // Вторичные изменения бокситов из месторождений СССР. - М.: Наука, 1980. - С. 239-249.

11. Слукин, А. Д. Латеритные коры выветривания и бокситы на траппах полуострова Кач, Индия / А. Д. Слукин // Кора выветривания. - 1991. - Вып. 20. - С. 91- 99. 
12. Sahasrabudhe, Y. S. Bauxite deposits of Gujarat, Maharashtra and parts of Karnataka / Y. S. Sahasrabudhe // Bull. of the Geol. Surv. of India. - Series A - Economic Geology. 1978. № $39 .-163 \mathrm{p}$.

13. Chitale, $D . V$. Natroalunite in a laterite profile over Deccan trap basalts at Matanumad, Kutch, India / D. V. Chitale, I. N. Guven // Clays and Clay Minerals. - 1987. - V. 35. - № 3. - P. 196-202.

14. Серова, В.В. Минералогия эоловой и водной взвеси Индийского океана / В.В. Серова. - М.: Наука, 1988. - 176 с. 15. Worden, R. H. Halogen elements in sedimentary systems and their evolution during diagenesis / R. H. Worden // Harlov D.E., Aranovich L. (Ed-s). The role of Halogen in terrestrial and extraterrestrial geochemical processes, surface, crust and mantle. Cham. Switzerland: Springer. Geochemistry. - 2018. -

16. Goldberg, E. D. The sediments of the northern Indian Ocean / E. D. Goldberg, J. J. Griffin // Deap-Sea Res. - 1970. -V. 17. P. 513-537.

17. Слукин, А. Д. Типоморфные особенности кристалломорфологии гиббсита латеритных бокситов как показатели его генезиса / А. Д. Слукин // Вестник Воронеж. гос. ун-та. Сер.: Геология. -2017 - № 4. - С. 51-57.

18. Изменение минерального и химического состава непогребенных латеритных бокситов в условиях изменившегося P. $185-260$.

климата / А. Д. Слукин [и др.] // Физико-химические и петрографические исследования в науках о Земле. Девятнадцатая международная конференция. Материалы конференции.М.: ИГЕМ РАН, 2018. - С. 302-305.

19. Биогенное растворение кварца в процессе образования латеритных бокситов (по результатам электронно-микроскопического изучения) / А. Д. Слукин [и др.] // ДАН. 2019. - T. 486. - № 2. - С. 228-232.

20. Биоминералы латеритных бокситов - новые данные по результатам электронно-микроскопического изучения / А. Д. Слукин [и др.] // Новые данные о минералах. 2016. B.51. - C. 52-61.

21. Ушатинская, Г. Т. Участие микроорганизмов в посмертной минерализации органики - основной фактор сохранения прижизненных органических структур в ископаемом состоянии / Г. Т. Ушатинская // Минералогия и жизнь: происхождение биосферы и коэволюция минерального и биологического миров, биоминералогия. Материалы IV международного семинара. Сыктывкар, 2007. - С. 68-69.

22. Biomineralization in bauxitic laterites of modern- and paleotropics of Earth / A. D. Slukin [et al.] // Biogenic-Abiogenic Interactions in Natural and Anthropogenic Systems / Editors: Frank-Kamenetskaya, Olga V., Panova, Elena G., Vlasov, Dmitry Yu. 2015. - Springer. - P. 67-75.

Institute of Geology of Ore Deposits, Petrography, Mineralogy, and Geochemistry, Russian Academy of Sciences, Moscow, Russia рографии, минералогии и геохимии Российской Академии Наук (ИГЕМ РАН), г. Москва

Слукин Анатолий Данилович, профессор, доктор геологоминералогических наук, ведущий научный сотрудник E-mail:slukin@igem.ru Тел.: +7(495) 2308224

Боева Наталья Михайловна, доктор геологоминералогических наук, ведущий научный сотрудник, E-mail:boeva@igem.ru

Тел.: +7(495) 2308436

ФГБУН Палеонтологический институт им. А. А. Борисяка Российской академии наук, (ПИН РАН), г. Москва

Жегалло Елена Александровна, кандидат геологоминералогических наук, старший научный сотрудник E-mail: ezheg@paleo.ru

Тел.: +7(495) 3399144

Зайчева Любовь Владимировна, старший научный сотрудник

E-mail:ezheg@paleo.ru; Tел.: +7(495) 3399144

Шипилова Елена Серафимовна, младший научный сотрудник

E-mail:lenusik.shipilva@rambler.ru

Тел.: +7(495) 2308436
Slukin A. D., Professor, Doctor of Geological and Mineralogical Sciences, leading researcher

E-mail:slukin@igem.ru

Tel.: +7(495) 2308224

Boeva N. M., Doctor of Geological and Mineralogical Sciences, leading researcher

E-mail:boeva@igem.ru

Tel.: +7(495) 2308436

Borisyak Paleontological Institute, Russian Academy of Sciences, Moscow, Russia

Zhegallo E. A., Candidate of Geological and Mineralogical

Sciences, senior researcher

E-mail:ezheg@paleo.ru

Tel.: +7(495) 3399144

Zaytseva L. V., senior researcher

E-mail:ezheg@paleo.ru

Tel.: +7(495) 3399144

Shipilova E. S., Junior researcher

E-mail: lenusik.shipilva@rambler.ru

Tel.: +7(495) 2308436 